\title{
AKTIVITAS EKSTAK ETANOL DAUN Alocasia macrorrhizos SEBAGAI ANTIOKSIDAN
}

\author{
Syarah Anliza ${ }^{1}$ \\ ${ }^{1}$ Jurusan Analis Kesehatan, Poltekkes Kemenkes Banten
}

\begin{abstract}
ABSTRAK
Penyakit degeneratif menjadi masalah utama kesehatan di Indonesia. Salah satunya diabetes militus. Penyakit ini ditandai dengan tingginya kadar gula dalam darah (hiperglikemia) yang disebabkan karena kerusakan sel dalam produksi insulin. Salah satu penyebab utama diabetes melitus dan adalah radikal bebas. Memperbaiki stress oksidatif adalah strategi yang efektif untuk menurunkan perkembangan diabetes dan komplikasinya. Antioksidan dalam jumlah yang cukup sangat penting bagi penderita diabetes untuk mencegah komplikasi. Salah satu upayanya yaitu menemukan senyawa-senyawa antioksidan pada tumbuhan. Tanaman Alocasia macrorrhizos ini dikenal sebagai tanaman sente, yang mengandung flavonoid. Metode yang digunakan adalah DPPH. Hasil penelitian menunjukkan bahwa antioksidan sebesar 550 ppm. Hal ini menunjukkan bahwa antioksidan bersifat lemah.
\end{abstract}

Kata kunci : Antioksidan, Daun Alocasia macrorrhizos, Ekstrak etanol

Korespondensi: Syarah Anliza. E-mail: syarah125@ gmail.com

\section{PENDAHULUAN}

Penyakit degeneratif menjadi masalah utama kesehatan di Indonesia. Salah satunya diabetes militus. Dibetes Melitus (DM) merupakan penyakit gangguan metabolik yang menjadi masalah utama kesehatan di dunia termasuk Indonesia. Penyakit DM ditandai dengan tingginya kadar gula dalam darah (hiperglikemia) yang disebabkan karena kerusakan sel dalam produksi insulin dan kerja insulin yang tidak optimal (WHO, 2006).

Salah satu penyebab utama diabetes melitus dan berbagai penyakit degeneratif lainnya adalah radikal bebas (Putri 2010). Pada penderita diabetes melitus, stres oksidatif akan menghambat pengambilan glukosa di sel otot dan sel lemak serta penurunan sekresi insulin oleh sel- $\beta$ di pankreas. Stres oksidatif secara langsung mempengaruhi dinding vaskular, sehingga berperan penting dalam patofisiologi terjadinya komplikasi diabetes tipe 2 (Putri 2010). Memperbaiki stress oksidatif adalah strategi yang efektif untuk menurunkan perkembangan diabetes dan komplikasi. Antioksidan dalam jumlah yang cukup sangat penting bagi penderita diabetes untuk mencegah komplikasi.

Salah satu upaya tersebut adalah mengeksplor dan menemukan senyawa-senyawa 
antioksidan seperti beta karoten, astasantin, alkaloid, dan fenol pada tumbuhan. Alternatif yang digunakan dari bahan alam, salah satunya adalah Alocasia macrorrhizos yang biasa dikenal dengan tanaman sente. Tanaman ini mengandung flavonoid, cynogenetik, glikosida, asam askorbat, asam galat, asam malat,asam oksalat, asam suksinat dan $\beta$-lektin (Rahman et al, 2012).

Tanaman Alocasia macrorrhizos dapat berguna sebagai antifungal, analgesik, antitumor dan antioksidan. Berdasarkan hasilnya pada ekstrak dietil eter dari akar, daun dan rhizom menunjukkan aktivitas antioksidan dengan $\mathrm{IC}_{50}$ sebesar $34.51 \pm 2.72$, $103.39 \pm 7.12$, dan $\quad 48.01 \pm 6.68 \mu \mathrm{g} / \mathrm{mL}$ (Srivastava el al, 2012).

Penelitian sebelumnya yang telah dilakukan oleh peneliti bahwa ektrak metanol pada dari Alocasia macrorrhizos menunjukan antioksidan dengan nilai IC50 yang diperoleh 314,885 ppm.Hal ni dimungkinkan karena bahan yang digunakan sangat polar dan sangat toksik. Oleh karena itu peneliti melanjutkan dengan bahan yang ramah lingkungan dan direkomendasikan oleh BPOM yaitu etanol sehingga penelitian ini dilanjutkan untuk mengetahui aktivitas ekstrak etanol dari daun Alocasia macrorrhiza sebagai antioksidan

\section{METODE PENELITIAN}

Jenis penelitian yang akan dilakukan adalah eksperimen, dengan melakukan uji aktivitas antioksidan pada ekstrak etanol dari daun Alocasia macrorrhizos. Populasi berasal dari pohon Alocasia macrorrhizos yang ada di daerah Pondok Labu, Jakarta Selatan. Sampel yang digunakan adalah daun Alocasia macrorrhizos yang segar dan berwarna hijau. Data yang digunakan dalam penelitian ini yaitu data primer dengan uji laboratorium isolasi dan uji antioksidan ekstrak etanol dari daun Alocasia macrorrhizos dan dilakukan uji fitokimia

\section{HASIL}

Hasil ekstrak etanol etanol daun Alocasia macrorrhiza mengandung komponenkomponen yang berfungsi sebagai antioksidan. Hasil uji fitokimia didapatkan daun Alocasia macrorrhiza dan ektrak etanol Alocasia macrorrhiza mengandung flavonoid $(+)$ dan steroid (+). Pengukuran aktivitas antioksidan pada ekstrak etanol daun Alocasia macrorrhizos dilakukan dengan menggunakan metode DPPH menghasilkan IC50 sebesar 550 ppm.

\section{PEMBAHASAN}

Hasil uji fitokimia pada ekstrak etanol daun Alocasia macrorrhizos menunjukkan bahwa positif terhadap flavonoid dan steroid. Flavonoid berperan penting dalam biokimia dan fisiologi tanaman baik sebagai antioksidan, inhibitor enzim dan prekursor bagi komponen toksik. Hal ini diisebabkan karena ektrak etanol bersifat polar sehingga hanya dapat mengikat senyawa kimia yang bersifat polar seperti flavonoid dan steroid. Flavonoid memiliki peranan sebagai antimikroba dan antivirus (Yuefei et al, 2012). 
Pengukuran aktivitas antioksidan pada ekstrak etanol daun Alocasia macrorrhiza dilakukan dengan menggunakan metode DPPH. Aktivitas antioksidan hasil penelitian dinyatakan dalam IC50, yaitu konsentrasi zat antioksidan yang menghasilkan persen penghambatan DPPH sebesar $50 \%$. Berdasarkan nilai IC50 yang diperoleh, ekstrak etanol daun Alocasia macrorrhiza memiliki aktivitas antioksidan dengan nilai IC50 sebesar $550 \mathrm{ppm}$ dan tergolong antioksidan tidak aktif. Aktivitas antioksidan yang lemah kemungkinan disebabkan oleh struktur kimianya yang tidak memiliki gugus hidroksi fenolik yang banyak dan tidak memiliki ikatan rangkap pada C2-C3 pada struktur flavonoid, yang dapat meningkatkan kapasitas stabilisasi radikal flavonoid yang terbentuk. Oleh karena itu aktivitas antioksidan kemungkinan hanya disumbangkan oleh gugus hidroksi fenolik pada cincin lainnya. Selain itu kemungkinan disebabkan juga oleh efek tidak sinergis dari metabolit sekunder didalam ekstrak tersebut, dimana kandungan metabolit sekunder alkaloid yang seharusnya memiliki aktifitas antioksidan daripada metabolit sekunder lain tetapi pada ekstrak etanol daun Alocasia macrorrizhos tidak terdapat kandungan senyawa alkaloid. Faktor-faktor yang menghasilkan perbedaan aktivitas yaitu perbedaan kemampuan dalam mentransfer atom hidrogen ke radikal bebas, dan struktur kimia senyawa antioksidan (Widyawati, 2012).

\section{KESIMPULAN}

Analisis kualitatif yang dilakukan pada ekstrak etanol daun Alocasia macrorrizhos menunjukkan bahwa mengandung senyawa flavonoid, dan steroid. Analisis kuantitatif pada aktivitas antioksidan menunjukkan bahwa nilai IC50 yang diperoleh 550 ppm. Berdasarkan hasil penelitian, maka dapat disimpulkan bahwa ekstrak etanol daun Alocasia macrorrizhos memilki antioksidan tetapi bersifat lemah.

\section{DAFTAR PUSTAKA}

Putri DR. 2010. Efek antioksidan fraksi larut etil asetat ekstrak etanol daun jambu biji (Psidium guajava L.) pada kelinci yang dibebani glukosa. [skripsi]. Surakarta: Fakultas Farmasi Universitas Muhammadiyah Surakarta.

Rahman, Masudur., Hossain, Aslam., Alam, Saiful Siddique, Parvej, Kaishar BIPLAB， Uddin, Helal. 2012. Antihyperglycemic, antioxidant, and, cytotoxic activities of Alocasia macrorrhizos (L) rhizome extract. Turk J Biol. 36: 574 - 579

Srivastava, Vivek, Mubeen, Sheikh, Chand, Bhupesh Semwal, Misra, Vimlesh. 2012. Biological Activities Of Alocasia Macrorrhiza : a Review. Journal of Science. ISSN- 2277 - 1883.

Yuefei, W., Shuangru,H., Shuhong, S., Lisheng.,Q., and Ping., X. 2012. Studies in bioactivities of tea (Camellia sinensis L) fruit peel extract: Antioxidant activity and inhibitory potential against alphaglucosidase and alpha-amylase in vitro. 
Indrustrial Crops and Product 37, 520-

526.

[WHO] World Heatlh Organization. 2014.

Prevalence of diabetes worldwide.

[Internet]. [diunduh 2017 Maret 20].

Tersedia pada

http://www.who.int/mediacentre/factshe ets/fs312/en/ 